\title{
Survival of Escherichia coli, Pseudomona aeruginosa, Staphylococcus aureus on Wood and Plastic Surfaces
}

Alan Hedge*

Department of Design and Environmental Analysis, Cornell University, Ithaca, USA

\begin{abstract}
The survival of (Escherichia coli, Pseudomona aeruginosa, and Staphylococcus aureus was tested on natural beech wood, varnished beech wood, and plastic at 5 times:immediately after surface contamination and drying; 24 and 48 hours after contamination; 24 hours after contamination the samples were cleaned with non-germicidal detergent cleaner (Triton X-100 at a 1:30 dilution with distilled water) and surface bacteria were sampled a further 24 hours after cleaning. Initial E. coli and $P$. aeruginosa counts were highest for plastic, followed by varnished beechwood, and lowest for the natural beech wood. On each surface these bacteria died off almost completely within 24 hours. Initial S. aureus counts were highest for plastic, followed by varnished beech wood, and lowest for the natural beech wood. For all surfaces, there was an initial reduction from drying, but after 24 hours the counts plateaued, suggesting that bacteria could have survived on the surfaces for quite some time. At 24 hours the counts were comparable on all 3 surfaces. However, 48 hours after surface washing $S$. aureus could not be detected on the untreated beech wood, but this was still detectable on the varnished beech wood and plastic. Implications are discussed.
\end{abstract}

Keywords: Escherichia coli; Pseudomona aeruginosa; Staphylococcus aureus; Beech wood; Plastic

\section{Introduction}

Pathogenic bacteria can cause a variety of diseases [1]. Some strains of the gram negative bacterium Escherichia coli (E.coli) are the leading causes of severe abdominal cramps and bloody diarrhea in children [2-4]. Opportunistic gram negative pathogenic bacteria, such as Pseudomona aeruginosa (P. aeruginosa), can cause respiratory tract, urinary tract and ear infections [5-7]. Pathogenic gram positive bacteria, such as Staphylococcus auereus (S. auereus) can cause of range of illnesses, from minor skin infections to potential fatal diseases like pneumonia and meningitis [8]. Previous work has shown that pathogen survival is affected by the surface materials, and natural woods have better hygienic properties than plastic [8]. Maintaining a hygienic environment for a child is especially important to managing these illness risks. The present study compared immediate, 24 hours and 48 hours survival for pathogenic bacteria on natural beech wood, varnished beech wood and plastic, and it also evaluated the effects of cleaning with a sterile disinfecting solution and drying a surface on subsequent bacterial survival at 24 hours and 48 hours.

\section{Method}

Two gram negative bacteria (E. coli and P. aeruginosa) and one gram positive bacterium ( $S$. aureus) were tested on three surfaces (natural beech wood, varnished beech wood and plastic), making 9 groups in total. Each species was tested in sequence to avoid any possibility of cross contamination. For each group, 5 test coupons were cut to 2 " long $(\sim 5 \mathrm{~cm}) \times 0.75$ " $(\sim 2 \mathrm{~cm})$ wide $\times 0.5$ " deep $(\sim 1.25 \mathrm{~cm})$, and then inoculated with the appropriate test bacterium and air dried at $35^{\circ} \mathrm{C}$ for 20 minutes. Immediately after the inoculum dried at "time 0 ," a single coupon from each group was harvested and enumerated. The remaining 4 coupons for each group were incubated in a foilcovered basin, with a water reservoir to increase humidity, at room temperature $\left(\sim 22^{\circ} \mathrm{C}\right)$ for 24 hours. After 24 hours, a single un-washed coupon from each of the 9 groups was harvested and enumerated. Two coupons from each group were randomly selected and cleaned using $0.100 \mathrm{ml}$ of a non-germicidal detergent cleaner (Triton X-100 at a 1:30 dilution with distilled water). Each coupon was then cleaned with a moist, sterile swab and subsequently dried with a dry sterile swab. The washed coupons were dried at room temperature for approximately 20 minutes. Immediately afterwards a single washed, dried coupon from each group was harvested and enumerated. The remaining coupons from each group (one washed, one not washed) were incubated at room temperature for a further 24 hours. After the second 24 hour incubation period (at time $=48$ hours), the two remaining coupons from each group were harvested and enumerated. The incubation times for all D/E (Dey/Engley) Neutralizing Agar plates were $>48$ hours to facilitate recovery of any injured bacteria. All enumerations were done by placing the samples aseptically in $10 \mathrm{~mL}$ sterile $\mathrm{D} / \mathrm{E}$ (Dey/ Engley) broth to neutralize and test any antiseptic or disinfectant effect, then vortexing vigorously, then analyzing using standard dilution and plating techniques. Because species counts were performed for single coupons, statistical methods cannot be applied to the data.

\section{Results}

At time 0 , the survival of E. coli, $P$. aeruginosa and $S$. aureus was lowest for natural beech wood and highest for plastic. Results at 24 hours show that E.coli and P. aeruginosa survival times were brief on all three surfaces. However, after 24 hours the $S$. aureus counts were highest for the plastic, lower for the varnished beech wood and lowest for the natural beech wood. At 48 hours, $S$. aureus counts were comparable on all 3 surfaces. After cleaning $S$. aureus was not detectable on the 24 hours sample of natural birch wood but it was detectable at comparable low levels for the varnished beech wood and the plastic (Figure 1).

*Corresponding author: Alan Hedge, Department of Design and Environmental Analysis, Cornell University, Ithaca, USA, Tel: 607255 1957; E-mail: ah29@cornell.edu

Received June 02, 2015; Accepted July 01, 2015; Published July 08, 2015

Citation: Hedge A (2015) Survival of Escherichia coli, Pseudomona aeruginosa, Staphylococcus aureus on Wood and Plastic Surfaces. J Microb Biochem Technol 7:4 210-212. doi:10.4172/1948-5948.1000207

Copyright: (c) 2015 Hedge A. This is an open-access article distributed under the terms of the Creative Commons Attribution License, which permits unrestricted use, distribution, and reproduction in any medium, provided the original author and source are credited. 
$\square$ P. aeruginosa $15442 \quad \square$ E. coli $11229 \quad$ - S. aureus ATCC 6538

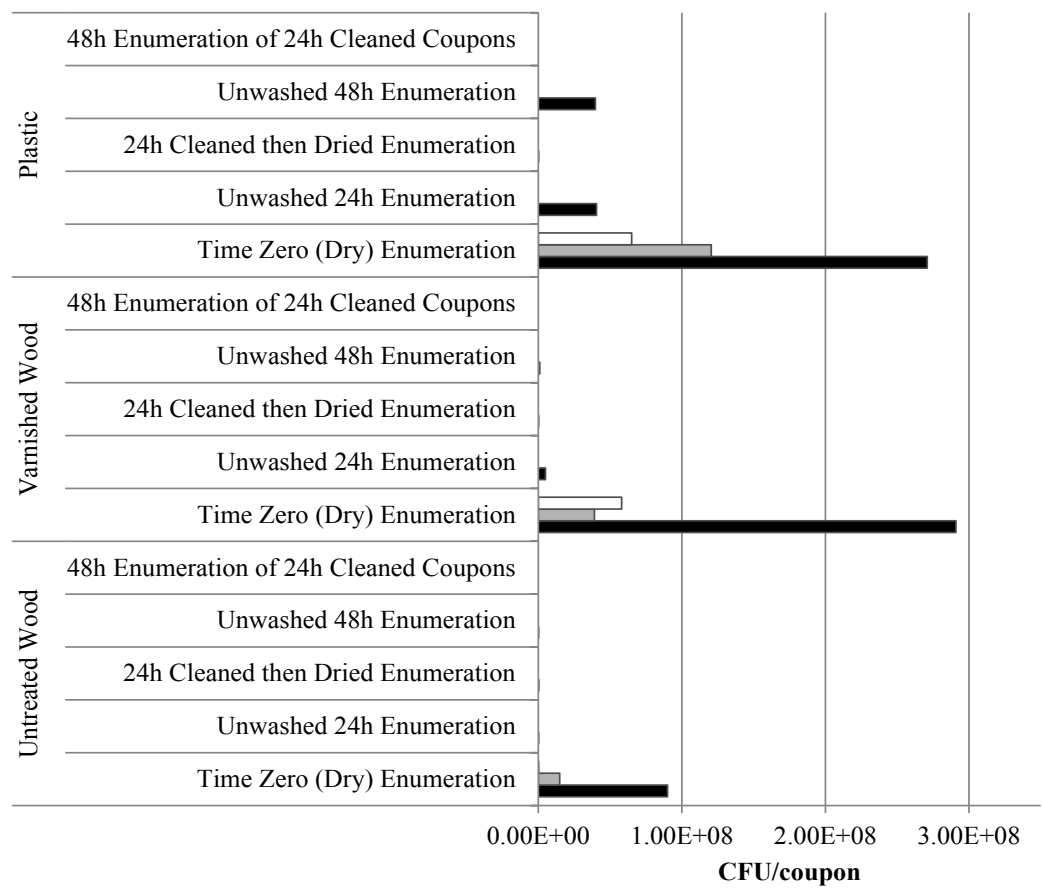

Figure 1: Surface survival of bacteria at each stage of the study.

\section{Discussion}

Research has shown for E. coli and E. faecium, pine and oak have better hygienic performance than plastic, possibly due to the hygroscopic properties of wood and the effects of wood extractives [9]. Reductions in bacterial numbers are also seen for spruce, larch, poplar and beech when compared with plastic [9]. Present findings confirm and extend these earlier results and show that for all surfaces gram negative bacteria (E. coli and $P$. aeruginosa) failed to survive within 24 hours, suggesting that these materials offer a low surfacemediated contact transmission risk. The gram negative bacteria tested were similar to pathogens implicated in surface-mediated disease transmission, such as Salmonella, Shigella, and Campylobacter, so these organisms could reasonably be expected to display the same quick and natural ( 24 hour) die-off due to desiccation alone. Although there is evidence that Salmonella can become acclimatized to desiccation stress, and induction of the desiccation stress response in bacterial cells makes them more resistant to the dry conditions in which they are present [10]. However, with natural wood there is also an effect of porosity that also reduces surface bacteria counts.

For all surfaces there was an initial reduction in the $S$. aureus count from drying, but residual contamination at 48 hours suggests that $S$. aureus may survive on dry surfaces for more extended periods. This also may occur with other gram positive bacteria, like Enterococcus and Streptococcus. Interestingly, current hospital pathogens of concern include MRSA (methicillin-resistant Staphylococcus aureus) and VRE (Vanocomycin-resistant Enterococci) and both are gram positive, and Clostridium difficile which has great surface survival capability in its endospore form.

Natural beech wood was the most effective of the 3 surfaces tested in this study with fewest recoverable bacteria immediately after initial drying of the inoculum. This could have been a result of either a "quick initial killing" property of the wood, or more likely, from the bacteria irreversibly entering cavities in the wood and subsequently dessicating. From observation when the inoculum was applied to the different surfaces it spread farther over the natural beech wood surface and dried quickest, and this would result in fewer bacteria per unit of surface area than the inoculated area of either the varnished beech wood or plastic and this in turn lowers the risk for transfer from a single, fingerpadsized surface touch contact events.

\section{References}

1. WHO (2008) The World Health Report 2008: Primary HealthCare-Now More Than Ever.

2. Centers for Disease Control (CDC) (2005) Enterotoxigenic Escherichia coli (ETEC).

3. Qadri F, Svennerholm A, Faruque AS, Bradley Sack R (2005) Enterotoxigenic Escherichia coli in developing countries: Epidemiology, microbiology, clinical features, treatment, and prevention. Clinical Microbiology Reviews 18: 465-483.

4. Subekti DS, Lesmana M, Tjaniadi P, Machpud N, Sriwati N, et al. (2003) Prevalence of enterotoxigenic Escherichia coli (ETEC) in hospitalized acute diarrhea patients in Denpasar, Bali, Indonesia. Diagnostic Microbiology and Infectious Disease 47: 399-405.

5. Centers for Disease Control (CDC) (2014) Pseudomonas aeruginosa in Healthcare Settings.

6. Carmeli Y, Troillet N, Eliopoulos GM, Samore MH (1999) Emergence of antibiotic-resistant $P$ seudomonas aeruginosa: comparison of risks associated with different anti pseudomonal agents. Antimicrob Agents Chemother 43: 1379-1382.

7. Cheng YL, Lee HC, Yeung CY, Chan WT (2009) Clinical significance in previously healthy children of Pseudomonas aeruginosa in the stool. Pediatr Neonatol 50: 13-17. 
Citation: Hedge A (2015) Survival of Escherichia coli, Pseudomona aeruginosa, Staphylococcus aureus on Wood and Plastic Surfaces. J Microb Biochem Technol 7:4 210-212. doi:10.4172/1948-5948.1000207

8. Centers for Disease Control (CDC) (2006) Staphylococcal Food Poisoning.

9. Milling A, Kehr RD, Wilf A, Smith K (2005) Survival of bacteria on wood and plastic particles: Dependence on wood species and environmental conditions. Holzforschung 59: 72-81.
10. Chen Z, Diao J, Dharmasena M, lonita C, Jiang X, et al. (2013) Therma inactivation of desiccation-adapted Salmonella spp. in aged chicken litter. Applied and Environmental Microbiology 79: 7013-7020. 